\title{
Demutualization and Demand for Reinsurance
}

\author{
Jennifer L. Wang ${ }^{\mathrm{a}}$, Vincent Y. Chang ${ }^{\mathrm{b}}$, Gene C. Lai ${ }^{\mathrm{c}}$ and \\ Larry Y. Tzeng ${ }^{\mathrm{b}}$ \\ ${ }^{a}$ Risk Management and Insurance Department, National Cheng-chi University, \#64, Sec. 2, Chi-Nan Road, \\ Taipei 116, Taiwan. \\ E-mail: jenwang@nccu.edu.tw \\ ${ }^{\mathrm{b}}$ Finance Department, National Taiwan University, Taipei, Taiwan. \\ E-mails: d91723001@ntu.edu.tw, tzeng@ntu.edu.tw \\ ${ }^{c}$ Department of Finance, Insurance, and Real Estate, PO Box 644746, Pullman, WA 99164-4746, U.S.A. \\ E-mail: genelai@wsu.edu
}

This study investigates whether U.S. property-liability insurers change their demand for reinsurance after demutualization. Our empirical results show that the overall demand for reinsurance of converting insurers is not statistically different after the conversion. Furthermore, we find that converting insurers decrease the demand for reinsurance from non-affiliated reinsurers, but increase the demand for reinsurance from affiliated reinsurers after the conversion. One possible explanation is that converting insurers may treat reinsurance to affiliated reinsurers as risk retention rather than risk transfer so that they can reduce reinsurance cost. Another interesting finding is that converting insurers increase demand for reinsurance from non-affiliated reinsurers before conversion.

The Geneva Papers (2008) 33, 566-584. doi:10.1057/gpp.2008.17

Keywords: demand for reinsurance; property-liability insurance; demutualization; affiliated reinsurers; non-affiliated reinsurers; risk retention

\section{Introduction}

To protect against non-diversifiable risks, insurers traditionally have used the reinsurance market as a hedge. The ceding insurer can reduce its cash flow volatility and mitigate its financial pressure by transferring risk to reinsurance companies. Thus, purchasing reinsurance represents an important mechanism insurers use to limit their risk. In addition, such purchases shift some portion of the insurer's risk to reinsurers and reduce the probability and expected cost of potential bankruptcy. As a result, reinsurance contracts can be viewed as indispensable and effective risk management tools that insurers employ to confront unexpected losses. ${ }^{1}$

Prior studies have modeled the demand for reinsurance by considering motives such as investment incentives, probability of bankruptcy, tax effects, and the availability of real services. ${ }^{2}$ They also find empirical evidence that the size, profitability, geographic concentration, and line of business concentration reduce the demand for reinsurance,

\footnotetext{
${ }^{1}$ Mayers and Smith (1990); Garven and Lamm-Tennant (2003).

${ }^{2}$ Ibid.; Cole and McCullough (2006).
} 
whereas tax-favored characteristics, direct business written, and under-loss reserves increase demand for it.

Mayers and Smith $^{3}$ suggest that the organizational form of the insurers could influence their risk-taking behavior and alter the demand for reinsurance. Their empirical results show that stock insurers purchase less reinsurance than do mutual insurers. However, several subsequent empirical papers, such as by Garven and Lamm-Tennant ${ }^{4}$ and Cole and McCullough, ${ }^{5}$ use different data and/or an alternative methodology to reexamine this issue and find evidence that leads them to conclude that stock insurers demand less reinsurance than do the mutuals. In other words, the empirical evidence is mixed. The purpose of this paper is to provide additional evidence and shed light on this issue by using time-series data and new methodology.

Most previous research has investigated whether stock insurers demand less reinsurance than mutual insurers by using cross-sectional data. In this paper, we reexamine this issue with a specific sample of demutualization insurers. Our approach may be better because we examine the demand for reinsurance for the same insurers before and after the conversions rather than different insurers (stock insurers versus mutual insurers). Using the same insurers has the advantages of allowing us to observe the changes in demand for reinsurance before and after the conversions. In addition, most of the prior studies use reinsurance ratios to measure the demand for reinsurance. As suggested by Powell and Sommer, ${ }^{6}$ a reinsurance ratio may be biased because it double counts direct and retroceded premiums in inter-company pooling arrangements. To avoid this problem, we separate the effect of reinsurance transfer of affiliated reinsurers from non-affiliated reinsurers. Finally, we conduct a two-stage selection regression model. In the first stage we examine whether or not an insurer demutualized, and in the second stage we investigate the changes in reinsurance demand during the sample period. The two-stage selection regression model is used to control for the joint endogeneity problem, which may be caused in the selection issue.

We use recent property-liability insurance conversions during 1990-2004 as our sample. We find that converting insurers decrease their demand for reinsurance from non-affiliated reinsurers but increase their demand for reinsurance from affiliated reinsurers. Thus, the overall demand for reinsurance after the conversions is not statistically different. In other words, we are not able to reject the hypothesis that, all else being equal, demutualized insurers reduce their overall demand for reinsurance after conversion. We also find that the demand for reinsurance from non-affiliated reinsurers is higher before the conversion. The results are robust when we exclude from our sample converting insurers whose purposes of converting are related to mergers and acquisitions (M\&A).

We organize this paper as follows. In the following section, we present the main hypothesis, discuss the database and variables, and further construct the empirical analysis framework. We then report empirical results in the next section. In the

\footnotetext{
${ }^{3}$ Mayers and Smith (1990).

${ }^{4}$ Garven and Lamm-Tennant (2003).

${ }^{5}$ Cole and McCullough (2006).

${ }^{6}$ Powell and Sommer (2007).
} 
penultimate section, we discuss robustness analyses and the M\&A issues. Finally, the final section concludes the paper.

\section{Research hypothesis and empirical analysis}

\section{Research hypothesis}

In this paper, we extend the line of research regarding demand for reinsurance by using a sample of demutualization insurers. Why do mutual insurers undergo the organizational structure change? A number of previous studies have proposed some solid explanations, such as financial distress and risk diversification, efficiency arguments, agency cost considerations, and constraints on financial market. ${ }^{7}$ Viswanathan and Cummins ${ }^{8}$ find that the property-liability mutuals with lower surplus-to-asset ratios are more likely to demutualize and that converting life-health mutuals tend to hold a significantly lower proportion of liquid assets. In addition, mutual insurers may take advantages from the conversion process by considering accounting effects. Mayers and $\mathrm{Smith}^{9}$ indicate that converting firms manage accounting information primarily by adjusting liabilities and selectively establishing investment losses. Other factors (such as line of business Herfindahl index, operating ratio, and long tail lines) may also affect the conversion decision, but do not yield the conclusive empirical results.

As mentioned above, Mayers and Smith $^{10}$ suggest that a mutual firm likely has greater difficulty accessing sources of new capital in the event of a large loss and therefore purchases more reinsurance. Thus, we expect that demutualized insurers will decrease their demand for reinsurance after they convert into stock insurers and define the main research hypothesis as follows:

Hypothesis: All else being equal, converting insurers reduce their demand for reinsurance after conversion.

\section{Data and variables description}

We use recent property-liability conversions during 1990-2004 as our sample. Appendix 1 presents the list of the demutualization sample insurers. Financial data for the insurance companies are obtained from the NAIC (National Association of Insurance Commissioners) Property and Casualty Database. We include only those samples with complete data during the entire sample period and thus consider only 36 demutualization insurers. ${ }^{11}$ The reason for using a 15 -year sample period but not

${ }^{7}$ Fitzgerald (1973); McNamara and Rhee (1992); Jenget al. (2007); Viswanathan and Cummins (2003); Viswanathan (2006).

${ }^{8}$ Viswanathan and Cummins (2003).

${ }^{9}$ Mayers and Smith (2004).

${ }^{10}$ Mayers and Smith (1990).

${ }^{11}$ For the 36 demutualization firms in Appendix 1, the conversion years for 1991-1999 are identified in Viswanathan and Cummins (2003), whereas those for 2000-2003 are identified from Best's Insurance Reports - Property-Liability. Not all demutualized firms from Viswanathan and Cummins (2003) appear herein because only the demutualized firms with all available data are adopted. 
longer is that we can evaluate the changes in the demand for reinsurance of demutualized insurers based on homogeneous economic conditions. ${ }^{12}$

For each demutualized insurer, we select its matching mutual insurers on the basis of commercial lines ratio as well as the firm assets. Specifically, we follow a variation of matching procedure from Barber and Lyon ${ }^{13}$ and Nohel and Tarhan. ${ }^{14}$ By using a two-dimensions (commercial lines ratio and size) sample selection method, we reduce sample selection bias. The demand for reinsurance is often driven by product mix. Thus, we first choose matching insurers on the basis of commercial line ratio and then further control the size to determine the final matching samples. ${ }^{15}$ Specifically, the restrictions, where percentages are potential deviations from the converting firm's value, are as follows: for commercial lines positive/negative, 1.5 percent, for size positive/negative, 1.5 percent. ${ }^{16}$ As a result, for each demutualized insurer, we identify six mutual matching insurers. Thus, we can compare the changes of demand for reinsurance between the demutualized insurers and their counterpart matching insurers before and after the demutualization.

While prior studies use reinsurance ratios to measure the demand for reinsurance, ${ }^{17}$ we use the changes in reinsurance ratios as dependent variables. Specifically, $\Delta$ (reins_ratio $)^{18}$ represents the changes of reinsurance ratio where reins_ratio is (affiliated reinsurance ceded + non-affiliated reinsurance ceded)/(direct business written plus reinsurance assumed). However, Powell and Sommer ${ }^{19}$ suggest that the reinsurance ratio may be biased because it double counts direct and retroceded premiums in the inter-company pooling arrangement. To avoid this problem, we also separate the effect of reinsurance transfer of affiliated reinsurers from non-affiliated reinsurers. Specifically, we define $\Delta$ (reins_non_ratio) and $\Delta$ (reins_aff_ratio) as the changes in reins_non_ratio measured by (non-affiliated reinsurance ceded)/ (direct business written plus reinsurance assumed) and reins_aff_ratio measured by (affiliated reinsurance ceded)/(direct business written plus reinsurance assumed), respectively. ${ }^{20}$ The above two variables also allow us to test whether the converting insurers demand more reinsurance from affiliated reinsurers and/or non-affiliated reinsurers.

${ }^{12}$ For more detailed discussion, see Viswanathan and Cummins (2003).

13 Barber and Lyon (1996).

14 Nohel and Tarhan (1998).

${ }^{15}$ For robustness, we use three different methods to select the matching samples: (1) by asset only; (2) first by asset then further control for commercial lines ratio; (3) first by commercial lines ratio and then by asset. The main results are similar.

${ }^{16}$ We can put more restrictions on other variables such as single dummy, but it will reduce the matching sample size dramatically.

${ }^{17}$ Mayers and Smith (1990); Garven and Lamm-Tennant (2003); Cole and McCullough (2006).

${ }^{18}$ For example, $\Delta$ (reins_ratio $\left.(-3)\right)=($ reinsurance ratio of year -3$)-($ reinsurance ratio of year -1$)$. Therefore, it represents the change of the reinsurance ratios between 3 years and 1 year before demutualization.

${ }^{19}$ Powell and Sommer (2007).

${ }^{20}$ For robustness, we also examine the change of the logarithm values of all above reinsurance ratios in the regression analyses. The main results of the regression are similar. 
Previous research also suggests several firm-specific characteristics, in addition to organizational form, which may affect the demand for reinsurance. ${ }^{21}$ We define our explanatory variables based on the characteristics accordingly.

First of all, the main explanatory variable, demutualized firm dummy variable (demutual_firm dummy), equals 1 if the insurer is the demutualized insurer and 0 otherwise. We use this dummy variable to test the main research hypothesis.

With regard to bankruptcy characteristics, we use three variables. First, firm size (Inasset), the natural logarithm admitted assets, is used as a proxy of the firm size. ${ }^{22}$ Prior studies predict that firm size has a negative impact on the demand for reinsurance, because small insurers should purchase more reinsurance to reduce their probability of bankruptcy. Second, Garven and Lamm-Tennant ${ }^{23}$ and Cole and $\mathrm{McCullough}^{24}$ predict a positive relationship between direct business written to surplus and demand for reinsurance. Insurers writing more business relative to their surplus should have a higher insolvency probability and therefore have greater demand for reinsurance. As a proxy for leverage, we consider the direct business written to surplus (leverage). ${ }^{25}$ Third, we use two-year loss development (2 year$s_{-}$loss $)^{26}$ to measure potential financial constraints. ${ }^{27} \mathrm{An}$ insurer with a positive loss development (under-loss reserving) needs more reinsurance to mitigate its potential financial constraints, whereas an insurer with a negative loss development (over-loss reserving) would have less demand for reinsurance. Thus, insurers that adjust their loss reserving will change their demand for reinsurance to target their financial objectives.

To control for profitability, we use return on assets $(R O A)^{28}$ to measure the profitability of insurers on the basis of their net investment gain divided by assets. Insurers that earn more profits are better able to face losses and financial pressures and thus demand fewer reinsurance contracts, according to Mayers and Smith, Powell and Sommer, Mayers and Smith, and Cole and McCullough. ${ }^{29}$

In addition, we incorporate tax-exempt investment income relative to total investment income (tax_ex) as a proxy for the expected tax liability or tax-favored assets. ${ }^{30}$ The structure of a tax code affects insurers' demand for reinsurance. On the one hand,

${ }^{21}$ Mayers and Smith (1990); Garven and Lamm-Tennant (2003); Cole and McCullough (2006).

${ }^{22}$ Mayers and Smith (1990); Hoyt and Khang (2000); Garven and Lamm-Tennant (2003); Weiss and Chung (2004); Cole and McCullough (2006).

${ }^{23}$ Garven and Lamm-Tennant (2003).

${ }^{24}$ Cole and McCullough (2006).

${ }^{25}$ Many prior studies also use liabilities-to-equity as a proxy for bankruptcy. For consistent comparison, we follow Cole and McCullough (2006) and use direct business written to surplus in this paper.

${ }^{26}$ The variable equals the development of estimated losses and loss expenses incurred 2 years before the current and prior year, scaled by policyholders' surplus. The data come from the 5-year historical page of the NAIC Property and Casualty Database.

${ }^{27}$ Petroni (1992); Weiss (1985); Grace (1990); Christensen et al. (1999); Gaver and Paterson (1999); Cole and McCullough (2006).

${ }^{28}$ Other studies also use ROE (return on equity) or ROC (return on capital) to measure profitability. We rely on Cole and McCullough's (2006) ROA definition to examine the relationship between profitability and demand for reinsurance for consistency. The use of ROA instead of ROE or ROC is plausible.

${ }^{29}$ Mayers and Smith (1990); Powell and Sommer (2007); Mayers and Smith (2004); Cole and McCullough (2006).

${ }^{30}$ D'Arcy and Garven (1990); Garven and Lamm-Tennant (2003); Cole and McCullough (2006). 
insurers can reduce their earnings' volatility by purchasing more reinsurance and thereby reduce their expected tax liability. ${ }^{31}$ On the other hand, purchasing reinsurance can mitigate the effects of large unexpected losses and advantage from investment in tax-favored assets. ${ }^{32}$ As a result, insurers that purchase more reinsurance contracts can reduce their expected tax liabilities and benefit from tax-favored assets.

Following Mayers and Smith, Kim et al., Garven and Lamm-Tennant, and Cole and McCullough, ${ }^{33}$ we define two real services proxies: geographic Herfindahl index (geo_H), which provides a proxy for geographic concentration, ${ }^{34}$ and line of business Herfindahl index (bus_H) as a proxy for line of business concentration. ${ }^{35}$ In general, reinsurers not only provide the protection of large and/or unexpected losses to insurers but also supply real services in terms of specialized knowledge and economies of scale. Consequently, if insurers issue policies in multiple lines of business and/or diverse geographic areas, they may have a higher incentive to purchase more reinsurance because the more reinsurance they purchase, the more services the reinsurers provide. $^{36}$ As a result, from a real services hypothesis, a less business- or geographically concentrated insurer may demand more reinsurance. On the other hand, a reinsurance contract offers a mechanism to increase the diversification of risk for insurers. From the viewpoint of risk diversification, insurers with a higher concentration in a given line of business or geographic area may have a higher incentive to purchase more reinsurance. Thus, high levels of concentration may prompt greater demand for reinsurance. In contrast, if insurers issue policies in multiple lines of business and/or diverse geographic area, then the insurers may have a lower incentive to purchase more reinsurance. ${ }^{37}$ As a result, a higher business- or geographically concentrated insurer may demand more reinsurance. According to these conflicting expectations, the influence of business concentration and geographic concentration is ambiguous.

Cole and McCullough ${ }^{38}$ separate affiliated and non-affiliated firms in their samples and control for the systematic differences with a single dummy variable; we use the dummy variable to control for the difference between affiliated and non-affiliated firms. We also include a group dummy, single (single), to indicate an affiliated insurer

${ }^{31}$ Mayers and Smith (1990); Smith and Stulz (1985).

${ }^{32}$ Garven and Lamm-Tennant (2003).

${ }^{33}$ Mayers and Smith (1990); Kim et al. (1996); Garven and Lamm-Tennant (2003); Cole and McCullough (2006).

${ }^{34}$ The definition of the geographic Herfindahl index follows Kim et al. (1996), who define it as the sum of the squares of the ratio of the dollar amount of direct business in state $j$ to the total amount of direct business across all states.

${ }^{35}$ Similar to the geographic Herfindahl index, the business Herfindahl index is defined as the sum of the squares of the ratio of the dollar amount of direct business written in a particular line of insurance to the dollar amount of direct business across all 26 lines of insurance (Mayers and Smith (1990)).

${ }^{36}$ The real services hypothesis for demanding reinsurance is actually a bias from heterogeneity of risk associated with lines of business and geographic locations written across carriers. Firms that underwrite concentrated exposures may choose less-risky insureds. It is impossible to directly determine this difference from NAIC data without more detailed classification. We thank one of the referees for pointing out this important issue.

37 Cole and McCullough (2006).

38 Ibid. 
or non-affiliated insurer, such that it equals 1 if the insurer is non-affiliated and 0 if it is affiliated. Insurers that belong to a group should demand more reinsurance, which enables them to shift profits within the group and reduce tax payments. Finally, we use premiums written in each line of business in the model ${ }^{39}$ to control for the impact of variations in lines of business on the demand for reinsurance. Mayers and Smith ${ }^{40}$ and Cole and $\mathrm{McCullough}{ }^{41}$ control for these variation effects in the different lines of business of their models because some lines of business may have particular effects on the demand for reinsurance, such as liability-related lines, in which higher agency costs give the insurer greater incentive to purchase more reinsurance.

\section{Regression model}

To examine whether demutualized insurers change their demand for reinsurance after conversion, we analyze the changes of the reinsurance ratio for the period of 3 years before and after conversion (i.e., $t=-1,-2,-3$ and $t=3,2,1)$. We also make pair comparisons between the converting insurers and their mutual matching insurers before and after conversion.

To further analyze how converting insurers change their demand for reinsurance, we conduct regression analyses. As suggested by Studenmund ${ }^{42}$ and Esho et al., ${ }^{43}$ potential feedback effects and selection effects may require the application of a simultaneous equations framework. To avoid the possible endogenous problems and sample selection bias simultaneously, we construct a two-stage selection regression model. The model also includes firm-specific factors and other important control variables used in the literature. Panel data method is used to examine the hypothesis proposed in the previous section.

Das et al. ${ }^{44}$ provide a non-parametric estimation of sample selection models for controlling these problems. ${ }^{45} \mathrm{We}$ follow their concept and construct the regression model as follows:

In the first stage, the selection equation is a binary response model as follows:

$$
\operatorname{Prob}\{\text { firm demutualized }=1\}=F\left(X_{1} \beta\right)
$$

where $F($.$) is Standard Normal CDF with N D(0,1) . X_{1}$ is a $N_{1} T_{1} \times K_{1}$ matrix, and there are $K_{1}$ explanatory variables indexed by $k=1, \ldots, K_{1}$. In addition, $X_{1}$ represents

${ }^{39}$ We measure this variable as the ratio of premiums written in each line of business to premiums written in all 27 lines of business. To avoid a singular matrix in the regression, Mayers and Smith (1990) and Cole and McCullough (2006) suggest that the model should exclude the financial guarantee, international, and reinsurance lines.

${ }^{40}$ Mayers and Smith (1990).

${ }^{41}$ Cole and McCullough (2006).

42 Studenmund (1997).

${ }^{43}$ Esho et al. (2004).

44 Das et al. (2003).

${ }^{45}$ Klaauw and Koning (2003) provide a parametric estimation for a sample selection model. They assume that the error terms of the selection model and of the regression model follow a bivariate normal distribution. 
the independent variables mentioned in Viswanathan and Cummins ${ }^{46}$ but excluded from the reinsurance ratio, and $\beta$ is a $K_{1} \times 1$ vector that represents the coefficients of $K_{1}$ explanatory variables.

In the second stage, the regression model is set up as follows:

$$
Y=X_{2} \alpha+\varepsilon
$$

where $Y$ denotes the changes of the reinsurance ratio and is a $N_{2} T_{2} \times 1$ vector with cross-sectional unit $i=1, \ldots, N_{2}$, and time-series unit $j=1, \ldots, T_{2} . X_{2}$ is a $N_{2} T_{2} \times K_{2}$ matrix, and there are $K_{2}$ explanatory variables indexed by $k=1, \ldots, K_{2}$. In addition, $X_{2}$ represents the independent variables mentioned in the previous section and the error correction terms from the selection model, and $\alpha$ is a $K_{2} \times 1$ vector that represents the coefficients of $K_{2}$ explanatory variables. Finally, $\varepsilon$ is $N_{2} T_{2} \times 1$ vector and refers to the disturbance terms following i.i.d. $N D\left(0, \sigma_{2}^{2}\right)$.

Following Das et al., ${ }^{47}$ we use the cross-validation $(\mathrm{CV})$ criterion to decide our needing specifications. ${ }^{48}$ The $\mathrm{CV}$ criterion is the sum of squares of predicted residuals. By using CV to minimize asymptotic mean-square error, where the bias goes to zero at the same rate as the standard deviation, we have the best fitted unbiased estimation in the regression model.

\section{Empirical results}

We report changes in the demand for reinsurance for converting and matching insurers in Table 1. Following Viswanathan and Cummins, ${ }^{49}$ we consider 1 year before demutualization $(t=-1)$ as the benchmark year. The results show that for overall reinsurance ratio, converting insurers increase their demand for reinsurance before conversion. For example, the mean of changes in demand for overall reinsurance at $t=-1$ is 4.1 percent higher than at $t=-3$. The results also show that converting insurers decrease their demand for overall reinsurance at $t=0$ and $t=1$, but increase the demand at $t=2$ and $t=3$ after conversion. For example, the mean of changes in demand for overall reinsurance at $t=0$ is 0.5 percent lower than at $t=-1$.

When we separate the demand for reinsurance of an affiliated reinsurer from the demand for reinsurance of a non-affiliated reinsurer, the results show that converting insurers decrease their demand for non-affiliated reinsurers after conversion. Specifically, Table 1 shows the changes in reinsurance for converting insurers (relative to $t=-1$ ) are $-2.7,-3.4,-5.2$, and -4.5 percent at $t=0,1,2,3$, respectively. On the other hand, the results also show that converting insurers increase their demand for affiliated reinsurance after conversion. In other words, the increase in demand for

\footnotetext{
${ }^{46}$ Viswanathan and Cummins (2003).

${ }^{47}$ Das et al. (2003).

${ }^{48}$ As Das et al. (2003) suggested, we add error term in each regression model, including error term, the square of error term, and the cube of error term that form the first-stage probit model (selection model). Therefore, we have overall seven different regression models. The CV criterion is the sum of squares of predicted residuals. Consequently, the minimized CV model is the best fitted model.

${ }^{49}$ Viswanathan and Cummins (2003).
} 
Table 1 Summary statistics of the changes of the reinsurance ratio

\begin{tabular}{|c|c|c|c|c|c|c|c|c|c|c|c|}
\hline & \multicolumn{11}{|c|}{ Converting insurers versus mutual control insurers } \\
\hline & \multicolumn{3}{|c|}{$\Delta$ (reins_ratio) } & \multicolumn{4}{|c|}{$\Delta($ reins_non_ratio $)$} & \multicolumn{4}{|c|}{$\Delta($ reins_aff_ratio $)$} \\
\hline & $\begin{array}{c}\text { Converting } \\
\text { insurer }\end{array}$ & $\begin{array}{c}\text { Mutual } \\
\text { matching } \\
\text { insurer }\end{array}$ & $t$-test & & $\begin{array}{c}\text { Converting } \\
\text { insurer }\end{array}$ & $\begin{array}{c}\text { Mutual } \\
\text { matching } \\
\text { insurer }\end{array}$ & $t$-test & & $\begin{array}{c}\text { Converting } \\
\text { insurer }\end{array}$ & $\begin{array}{c}\text { Mutual } \\
\text { matching } \\
\text { insurer }\end{array}$ & $t$-test \\
\hline-3 & -0.041 & -0.012 & 0.78 & -3 & -0.046 & 0.0005 & 1.18 & -3 & -0.003 & -0.012 & -0.28 \\
\hline-1 & & & & -1 & & & & -1 & & & \\
\hline 0 & -0.005 & 0.003 & 0.3 & 0 & -0.027 & -0.001 & 0.99 & 0 & 0.0553 & 0.0078 & -0.88 \\
\hline 1 & -0.003 & 0.0022 & 0.14 & 1 & -0.034 & -0.004 & 0.93 & 1 & 0.0859 & 0.0074 & -1.18 \\
\hline 2 & 0.0497 & 0.0164 & -0.47 & 2 & -0.052 & 0.0094 & $1.7^{*}$ & 2 & 0.1243 & 0.0188 & -1.51 \\
\hline 3 & 0.047 & 0.0199 & -0.49 & 3 & -0.045 & 0.0022 & 1.53 & 3 & 0.185 & 0.0268 & $-1.81^{*}$ \\
\hline
\end{tabular}

This table reports the comparison of converting insurers versus mutual control insurers from year -3 to year +3 . The variables $\Delta$ (reins ratio),

$\Delta$ (reins_non_ratio), and $\Delta$ (reins_aff_ratio) are the difference values of (reinsurance ratio of each year minus reinsurance ratio of year -1$)$. We use the reinsurance ratio of year -1 as a benchmark year and compare it to other years.

*** significant at 1 percent, $* *$ significant at 5 percent, and *significant at 10 percent. 
reinsurance is driven by the increase in demand for reinsurance from affiliated reinsurers after conversion.

In addition to time-series comparisons, we also report the comparisons between the converting insurers and their matching mutual insurers. The evidence shows that converting insurers decrease the demand for reinsurance from non-affiliated reinsurers whereas matching insurers increase the demand for reinsurance from non-affiliated reinsurers. The evidence also shows that converting insurers increase demand more for reinsurance from affiliated reinsurers than the matching insurers. These results reinforce our conclusion that converting insurers decrease the demand for reinsurance from non-affiliated reinsurers, but increase demand for reinsurance from affiliated reinsurers.

Table 2 reports the summary statistics of the independent variables used in our regression analysis. The equal mean $t$-test is implemented to check whether or not the mean of these independent variables is significantly different between converting insurers and their matching insurers. We find that, compared with the mutual matching insurers, the characteristics of converting insurers are similar to those of matching insurers with few exceptions. First, converting insurers have lower geographic concentration relative to mutual matching insurers before and after conversion. Second, converting insurers are less likely to be a non-affiliated insurer after conversion. Overall, most of the means of the variables in Table 2 are similar to those in prior studies. ${ }^{50}$

The results of Table 1 do not control for firms' characteristics. We perform a twostage selection regression analysis to further examine the issue. The results of the regression analysis are showed in Table 3. Panel A shows the coefficient of demutual firm dummy is negative and significant when the change in demand for reinsurance from non-affiliated reinsurers is the dependent variable. On the other hand, the coefficient is positive and significant when the change in demand for reinsurance from affiliated reinsurers is the dependent variable. Not surprisingly, the coefficient of demutual firm dummy is not significant when the change in overall reinsurance ratio is the dependent variable. The overall evidence suggests that converting insurers decrease the demand for reinsurance from the non-affiliated reinsurers, but increase the demand for reinsurance from affiliated reinsurers after conversions. However, the overall demand for reinsurance is not statistically different after conversion.

Other major findings in Table 3 are reported below. The interaction term between the demutualized dummy and ROA variable is negatively correlated to overall demand for reinsurance. This result implies that converting insurers with higher profits decrease overall reinsurance after conversion. We find that the coefficient of the interaction term between demutualized dummy and leverage variable is positive and significant when the change in demand for reinsurance from non-affiliated reinsurers is the dependent variable, but the coefficient is negative and significant when the change in demand for reinsurance from affiliated reinsurers is the dependent variable. This is an interesting finding. It implies that converting insurers with higher leverage would

\footnotetext{
${ }^{50}$ Mayers and Smith (1990); Garven and Lamm-Tennant (2003); Cole and McCullough (2006).
} 
Table 2 Summary statistics of independent variables

\begin{tabular}{|c|c|c|c|c|c|c|c|c|c|}
\hline \multirow[b]{2}{*}{ Variables } & \multicolumn{3}{|c|}{ Year of -3} & \multicolumn{3}{|c|}{ Year of 0} & \multicolumn{3}{|c|}{ Year of 3} \\
\hline & $\begin{array}{l}\text { Converting } \\
\text { insurer }\end{array}$ & $t$-test & $\begin{array}{l}\text { Mutual matching } \\
\text { insurer }\end{array}$ & $\begin{array}{l}\text { Converting } \\
\text { insurer }\end{array}$ & t-test & $\begin{array}{c}\text { Mutual matching } \\
\text { insurer }\end{array}$ & $\begin{array}{l}\text { Converting } \\
\text { insurer }\end{array}$ & $t$-test & $\begin{array}{c}\text { Mutual matching } \\
\text { insurer }\end{array}$ \\
\hline tax_ex & 0.7444 & -0.67 & 0.6874 & 0.694 & -0.48 & 0.6582 & 0.6874 & -0.56 & 0.6509 \\
\hline roa & 0.0634 & -1.14 & 0.055 & 0.0575 & -0.14 & 0.0569 & 0.0472 & 0.21 & 0.0493 \\
\hline leverage & 2.9356 & -0.98 & 2.2066 & 1.8834 & 0.59 & 2.2759 & 2.2919 & -0.52 & 1.973 \\
\hline bus_H & 0.4667 & -0.06 & 0.4628 & 0.5073 & -0.27 & 0.4918 & 0.5448 & -0.88 & 0.4883 \\
\hline geo_H & 0.5074 & $4.55 * * *$ & 0.7949 & 0.5078 & $4.38 * * *$ & 0.7735 & 0.4976 & $3.69 * * *$ & 0.7543 \\
\hline 2_years_loss & -0.000031 & 0.52 & -0.000012 & -0.000016 & -1.08 & -0.00072 & -0.000055 & -0.03 & -0.000057 \\
\hline lnasset & 17.253 & 0.32 & 17.349 & 17.554 & 0.21 & 17.612 & 17.743 & 0.3 & 17.832 \\
\hline Single & 0.52 & 1.26 & 0.65 & 0.3667 & $3.43^{* * *}$ & 0.6806 & 0.28 & $3.22 * * *$ & 0.6129 \\
\hline Samples using & 25 & & 180 & 30 & & 216 & 25 & & 186 \\
\hline
\end{tabular}

This table shows the mean and equal mean $t$-test for independent variables, including samples of backward 3 years, forward 3 years, and current year of mutual matching firms. We show those mean and equal mean $t$-tests for converting insurers and matching firms, respectively. The variable of tax_ex is defined as taxexempt investment income relative to total investment income. And ROA is defined as net investment gain divided by assets. Concerning leverage, it is defined as direct business written to surplus. The geo_H variable is geographic Herfindahl index for insurers, which is defined as the sum of the squares of the ratio of the dollar amount of direct business in state $j$ to the total amount of direct business across all states. On the other hand, the bus_H variable is line of business

Herfindahl index for insurers, which is defined as the sum of the squares of the ratio of the dollar amount of direct business written in a particular line of insurance to the dollar amount of direct business across all 26 lines of insurance. The variable of 2_year_loss is two-year loss development; this variable equals the development of estimated losses and loss expenses incurred 2 years before the current and prior year, scaled by policyholders' surplus. The proxy of size is lnasset, and it is defined as natural logarithm of admitted assets. Finally, the group dummy is single, which is to indicate an affiliated or non-affiliated insure. It equals 1 if the insurer is non-affiliated and 0 if it is affiliated.

***significant at 1 percent, **significant at 5 percent, and *significant at 10 percent. 
increase their demand for reinsurance from non-affiliated reinsurers but decrease their demand from affiliated reinsurers after conversions. One possible explanation is that high leveraged converting insurers increase their demand for reinsurance from nonaffiliated reinsurers and decrease their demand from affiliated reinsurers to protect themselves from bankruptcy.

We also find that converting insurers with high business-concentrated insurers increase their demand for reinsurance from non-affiliated reinsurers after conversion. Finally, consistent with the literature, we find the coefficient of the interaction term between demutualized dummy and firm size is negative and significant, implying large converting insurers decrease their demand for reinsurance after conversions.

One may argue the result that converting insurers decrease their demand for reinsurance from non-affiliated reinsurers because of the substitution effect of more

Table 3 Regression results for converting and mutual matching firms after conversion

\begin{tabular}{|c|c|c|c|}
\hline Variables & $\Delta($ reins_ratio $)$ & $\Delta($ reins_non_ratio $)$ & $\Delta($ reins_aff_ratio $)$ \\
\hline \multicolumn{4}{|c|}{ Panel A Results of two-stage selection regression (with lnasset) } \\
\hline constant & $0.87964 * * *$ & $0.9668 * * *$ & 0.16427 \\
\hline tax_ex & -0.02475 & -0.03541 & 0.01419 \\
\hline roa & $1.04061 * *$ & $1.05964 * *$ & -0.28241 \\
\hline leverage & 0.000781 & $-0.00674 * * *$ & $0.00766^{* * *}$ \\
\hline bus_H & -0.07726 & $-0.1822 * * *$ & $0.1579 * * *$ \\
\hline geo_H & $0.08679 * *$ & $0.07769 * *$ & 0.01059 \\
\hline 2_years_loss & 0.07852 & 0.08285 & -0.06847 \\
\hline lnasset & -0.01276 & -0.01015 & $-0.01335^{*}$ \\
\hline single & -0.03364 & -0.00627 & $-0.05448 * * *$ \\
\hline demutual_firm dummy & 0.05926 & $-2.03734 * *$ & $2.01948 * * *$ \\
\hline demut dummy*tax_ex & 0.0881 & $0.18014 *$ & $-0.15609 *$ \\
\hline demut dummy*roa & $-2.46614^{* * *}$ & -0.70042 & -0.76487 \\
\hline demut dummy*leverage & 0.00202 & $0.02492 * *$ & $-0.02888 * * *$ \\
\hline demut dummy*bus_H & $0.23648^{*}$ & $0.29759 * *$ & -0.03613 \\
\hline demut dummy*geo_H & -0.12827 & -0.06332 & -0.06133 \\
\hline demut dummy*2_years_loss & 268.4595 & 264.745 & 76.28507 \\
\hline demut dummy*lnasset & $-0.09168 * * *$ & -0.02808 & $-0.08925^{* * *}$ \\
\hline demut dummy*single & -0.03094 & -0.02354 & -0.06177 \\
\hline$R^{2}$ & 0.2760 & 0.2897 & 0.2534 \\
\hline $\operatorname{Adj} R^{2}$ & 0.2263 & 0.2389 & 0.2038 \\
\hline$F$ value & $5.56 * * *$ & $5.70 * * *$ & $5.11 * * *$ \\
\hline Samples & 671 & 645 & 659 \\
\hline \multicolumn{4}{|c|}{ Panel B Result of two-stage selection regression (with lnequity) } \\
\hline constant & $0.87935 * * *$ & $1.0206 * * *$ & 0.07375 \\
\hline tax_ex & -0.02383 & -0.03393 & 0.01458 \\
\hline roa & $1.03315^{* *}$ & $1.05857 * *$ & -0.24625 \\
\hline leverage & 0.000377 & $-0.00724 * * *$ & $0.0076^{* * *}$ \\
\hline bus_H & -0.06515 & $-0.18171 * * *$ & $0.17465^{* * *}$ \\
\hline geo_H & $0.086^{* *}$ & $0.07759 * *$ & 0.01251 \\
\hline 2_years_loss & 0.07182 & 0.0768 & -0.03716 \\
\hline lnequity & $-0.01366^{*}$ & $-0.01312^{*}$ & -0.01005 \\
\hline single & -0.03305 & -0.00877 & $-0.05021 * * *$ \\
\hline demutual_firm dummy & -0.93251 & $-2.22955^{* * *}$ & $1.71876^{* * *}$ \\
\hline demut dummy*tax_ex & 0.09382 & $0.1761^{*}$ & $-0.16317^{*}$ \\
\hline demut dummy*roa & $-2.50755^{* * *}$ & -0.65743 & -0.83042 \\
\hline demut dummy*leverage & 0.00366 & $0.02472 * *$ & $-0.03176^{* * *}$ \\
\hline
\end{tabular}


Table 3 (continued)

\begin{tabular}{|c|c|c|c|}
\hline Variables & $\Delta($ reins_ratio $)$ & $\Delta($ reins_non_ratio $)$ & $\Delta($ reins_aff_ratio $)$ \\
\hline demut dummy*bus_H & $0.28523 * *$ & $0.29386^{* *}$ & -0.07446 \\
\hline demut dummy*geo_H & -0.06318 & -0.04529 & 0.00918 \\
\hline demut dummy*2_years_loss & 284.2739 & 246.5952 & 51.92801 \\
\hline demut dummy*lnequity & $-0.06033^{* *}$ & -0.02589 & $-0.06944 * * *$ \\
\hline demut dummy*single & -0.04087 & -0.01489 & -0.0643 \\
\hline$R^{2}$ & 0.2678 & 0.2913 & 0.2394 \\
\hline $\operatorname{Adj}_{-} R^{2}$ & 0.2176 & 0.2406 & 0.1875 \\
\hline$F$ value & 5.33 & $5.74 * * *$ & $4.62 * * *$ \\
\hline Samples & 671 & 645 & 659 \\
\hline
\end{tabular}

The table shows the regression results for converting and mutual matching firms after conversion of twostage selection regression for controlling the possible selection bias. To examine the substitution effect after demutualization, we replace lnasset with lnequity in Panel B. The dependent variables of $\Delta$ (reins_ratio), $\Delta$ (reins_non_ratio), and $\Delta$ (reins_aff_ratio) are the difference of (reinsurance of each year minus reinsurance ratio of year -1$)$. Independent variables include main firm-specific characteristics, interaction terms of dumutualized dummy variable and main firm-specific characteristics, and other control variables. The variable of tax_ex is defined as tax-exempt investment income relative to total investment income. And ROA is defined as net investment gain divided by assets. Concerning leverage, it is defined as direct business written to surplus. The geo_H variable is geographic Herfindahl index for insurers, which is defined as the sum of the squares of the ratio of the dollar amount of direct business in state $j$ to the total amount of direct business across all states. On the other hand, the bus_H variable is line of business Herfindahl index for insurers, which is defined as the sum of the squares of the ratio of the dollar amount of direct business written in a particular line of insurance to the dollar amount of direct business across all 26 lines of insurance. The variable 2_year_loss is two-year loss development; this variable equals the development of estimated losses and loss expenses incurred 2 years before the current and prior year, scaled by policyholders' surplus. The proxy of size is lnasset, and it is defined as natural logarithm of admitted assets. The group dummy is single, which is to indicate an affiliated or non-affiliated insurer. It equals 1 if the insurer is nonaffiliated and 0 if it is affiliated. Finally, the demutual_firm dummy equals 1 if the insurer is the demutualized insurer and 0 otherwise. On the other hand, the interaction terms of demutualized dummy variable and main firm-specific characteristics are also added into the regression model. They are labeled as demut dummy*(main firm-specific characteristics), respectively. The $R^{2}$, adjusted $\mathrm{R}^{2}, F$ value, and samples used are also reported.

$* * *$ significant at 1 percent, **significant at 5 percent, *significant at 10 percent.

capital after the conversion. To test whether our finding is entirely due to the substitution, we replace lnasset with lnequity. In other words, we control for the effect of more capital after the conversion. The results are presented in Panel B, Table 3. The results of Panel B are very similar to those of Panel A. Thus, the decrease in demand for reinsurance is not due to the substitution effect.

It should be noted that the above results are consistent with those of the literature. Two possible reasons are discussed here. First, most previous studies use crosssectional data of all insurers, whereas we use panel data related to converting and their matching insurers. Second, instead of the reinsurance ratio used in the previous studies, we consider the changes of reinsurance ratio as the dependent variable in our model and separate the demand for reinsurance into two categories: affiliated reinsurers and non-affiliated reinsurers.

In addition to the changes of reinsurance ratio, we further use the logarithm value of the changes of reinsurance ratio as a proxy for the demand for reinsurance as a 
Table 4 Results of demutualized firm dummy variable before converting for mutual matching firms

Results of ordinary least squares regression before converting (changes in Reins Ratio) mutual matching firms

\begin{tabular}{lccc}
\hline Coeff/Dep var & $\Delta$ (reins_ratio) & $\Delta$ (reins_non_ratio) & $\Delta$ (reins_aff_ratio) \\
demutual firm dummy & -0.01965 & $0.68719^{*}$ & -0.3685 \\
$T$ value & -0.05 & 1.78 & -0.78
\end{tabular}

This table shows the summary results of the demutualized firm dummy variable for the results of the ordinary least squares regression before converting for mutual matching firms. The dependent variables of $\Delta$ (reins_ratio), $\Delta$ (reins_non_ratio), and $\Delta$ (reins_aff_ratio) before converting are the difference of (reinsurance of year -1 minus reinsurance ratio of year -3 (and/or -2$)$ ). Independent variables include main firm-specific characteristics, interaction terms of demutualized dummy variable and main firm-specific characteristics, and other control variables.

***significant at 1 percent, **significant at 5 percent, and *significant at 10 percent.

robustness check. ${ }^{51}$ In general, the main results of the logarithm value model are consistent with the results in Table 3 and not tabulated here.

We also analyze the reinsurance behavior before converting. To save space, we only tabulate the main results of the regression analyses, which are shown in Table 4. We do not perform the two-stage selection regression model for this analysis since there is no selection bias problem in the matching group. Table 4 shows that demutualized insurers increase significantly more their demand for reinsurance from non-affiliated reinsurers before converting than the mutual controlling insurers. ${ }^{52}$

This result is interesting because we find that the demand for reinsurance from nonaffiliated reinsurers is lower after the conversion while the demand from non-affiliated reinsurers is higher before conversion. A possible reason is that demutualization needs to be approved by policyholders and regulators. Managers may increase their demand for reinsurance to show that the insurers have low risk before the approval of policyholders and regulators. Increasing demand for reinsurance from non-affiliated reinsurers would appear more creditable than from affiliated reinsurers before the conversion. After the conversion, the converting insurers decrease the demand for reinsurance because they no longer need the approval.

\section{Robustness of results}

Whether M\&A activities have an impact on the demand for reinsurance is an important question because insurers may reduce the demand for reinsurance when they become a large insurer after demutualizations. To further investigate this issue, we categorize our whole sample into $M \& A$ insurers sample and non-M\&A insurers sample. We identify eight demutualized insurers who initialized the converting process for M\&A purposes and exclude them from our sample. The regression results

\footnotetext{
${ }^{51}$ When implementing the logarithm value model, we cannot run the $\Delta \ln$ (reins_aff_ratio) model because most of the values of the affiliated reinsurance ceded of insurers are 0 , which creates zero denominator problems.

52 The result is consistent with Viswanathan and Cummins (2003).
} 
for non-M\&A insurers sample are reported in Table 5 and are similar to those of Table 3. We find that the demutualized insurers significantly decrease their demand for reinsurance from non-affiliated reinsurers, but increase their demand from affiliated reinsurers after conversion.

Table 5 Regression results for controlling M\&A activities after conversion

\begin{tabular}{|c|c|c|c|}
\hline Variables & $\Delta($ reins_ratio $)$ & $\Delta($ reins_non_ratio) & $\Delta($ reins_aff_ratio) \\
\hline \multicolumn{4}{|c|}{ Panel A Results of two-stage selection regression (with lnasset) } \\
\hline constant & $0.96999 * * *$ & $0.98886^{* * *}$ & 0.3212 \\
\hline tax_ex & -0.03033 & -0.04409 & 0.01544 \\
\hline roa & $1.6119^{* * *}$ & $1.42978 * * *$ & 0.02516 \\
\hline leverage & 0.000666 & $-0.00695 * * *$ & $0.00711 * * *$ \\
\hline bus_H & -0.10643 & $-0.19766^{* * *}$ & $0.19082 * * *$ \\
\hline geo_H & 0.07383 & $0.08561^{*}$ & -0.00509 \\
\hline 2_years_loss & 3.46588 & -12.7466 & 12.57041 \\
\hline lnasset & $-0.01705^{*}$ & -0.01154 & $-0.02384 * * *$ \\
\hline single & -0.03638 & -0.00646 & $-0.06917 * * *$ \\
\hline demutual_firm dummy & 0.16751 & $-2.68178 * * *$ & $3.21619 * * *$ \\
\hline demut dummy*tax_ex & 0.07355 & $0.19878^{*}$ & $-0.23976^{* *}$ \\
\hline demut dummy*roa & $-2.83575^{* * *}$ & -1.28886 & -0.8012 \\
\hline demut dummy*leverage & 0.00136 & $0.03883^{* * *}$ & $-0.04293 * * *$ \\
\hline demut dummy*bus_H & 0.27114 & $0.31066^{*}$ & -0.09623 \\
\hline demut dummy*geo_H & $-0.24 * *$ & -0.12517 & -0.08159 \\
\hline demut dummy*2_years_loss & 358.4626 & 274.6765 & 239.4198 \\
\hline demut dummy*lnasset & $-0.13307 * * *$ & -0.01897 & $-0.12615^{* * *}$ \\
\hline demut dummy*single & -0.09767 & -0.12579 & 0.0455 \\
\hline$R^{2}$ & 0.3073 & 0.3340 & 0.3094 \\
\hline $\operatorname{Adj} \_R^{2}$ & 0.2433 & 0.2698 & 0.2455 \\
\hline$F$ value & $4.80 * * *$ & $5.20 * * *$ & $4.84 * * *$ \\
\hline Samples & 509 & 490 & 497 \\
\hline \multicolumn{4}{|c|}{ Panel B Result of two-stage selection regression (with lnequity) } \\
\hline constant & $0.95113 * * *$ & $1.05714 * * *$ & 0.18168 \\
\hline tax_ex & -0.03116 & -0.04269 & 0.00763 \\
\hline roa & $1.57983 * * *$ & $1.42186^{* * *}$ & -0.12478 \\
\hline leverage & 0.000147 & $-0.00757 * * *$ & $0.0065 * * *$ \\
\hline bus_H & -0.08701 & $-0.19592 * * *$ & $0.21184 * * *$ \\
\hline geo_H & 0.0749 & $0.08562 *$ & -0.00208 \\
\hline 2_years_loss & -2.06445 & -17.0094 & 7.0272 \\
\hline lnequity & $-0.01766^{*}$ & -0.01545 & $-0.01797 * *$ \\
\hline single & -0.03422 & -0.00934 & $-0.06212 * *$ \\
\hline demutual_firm dummy & -0.94538 & $-2.91437 * * *$ & $1.79126^{* * *}$ \\
\hline demut dummy*tax_ex & 0.05696 & 0.19335 & $-0.22292 * *$ \\
\hline demut dummy*roa & $-2.78917 * * *$ & -1.24983 & -0.58809 \\
\hline demut dummy*leverage & 0.00142 & $0.03925^{* * *}$ & $-0.03938 * * *$ \\
\hline demut dummy*bus_H & $0.34096^{*}$ & $0.3169^{*}$ & 0.05642 \\
\hline demut dummy*geo_H & -0.16357 & -0.11102 & -0.0026 \\
\hline demut dummy*2_years_loss & 415.5622 & 273.3261 & 290.5611 \\
\hline demut dummy*lnequity & $-0.09677 * * *$ & -0.01375 & $-0.07929 * * *$ \\
\hline demut dummy*single & -0.12802 & -0.12257 & -0.02464 \\
\hline
\end{tabular}


Table 5 (continued)

\begin{tabular}{|c|c|c|c|}
\hline Variables & $\Delta($ reins_ratio $)$ & $\Delta($ reins_non_ratio $)$ & $\Delta$ (reins_aff_ratio) \\
\hline$R^{2}$ & 0.2934 & 0.3357 & 0.2813 \\
\hline Adj_$R^{2}$ & 0.2281 & 0.2716 & 0.2166 \\
\hline$F$ value & $4.49 * * *$ & $5.24 * * *$ & $4.34 * * *$ \\
\hline Samples & 509 & 490 & 497 \\
\hline
\end{tabular}

The table shows the regression results for converting and mutual matching firms after conversion of twostage selection regression for controlling M\&A activities. To examine the substitution effect after demutualization, we replace lnasset with lnequity in Panel B. The dependent variables of $\Delta$ (reins_ratio), $\Delta$ (reins_non_ratio), and $\Delta$ (reins_aff_ratio) are the difference of (reinsurance of each year minus reinsurance ratio of year -1 ). Independent variables include main firm-specific characteristics, interaction terms of demutualized dummy variable and main firm-specific characteristics, and other control variables. The variable of tax_ex is defined as tax-exempt investment income relative to total investment income. And ROA is defined as net investment gain divided by assets. Concerning leverage, it is defined as direct business written to surplus. The geo_H variable is geographic Herfindahl index for insurers, which is defined as the sum of the squares of the ratio of the dollar amount of direct business in state $j$ to the total amount of direct business across all states. On the other hand, the bus_H variable is line of business Herfindahl index for insurers, which is defined as the sum of the squares of the ratio of the dollar amount of direct business written in a particular line of insurance to the dollar amount of direct business across all 26 lines of insurance. The variable of 2_year_loss is two-year loss development; this variable equals the development of estimated losses and loss expenses incurred 2 years before the current and prior year, scaled by policyholders' surplus. The proxy of size is lnasset, and it is defined as natural logarithm of admitted assets. The group dummy is single, which is to indicate an affiliated or non-affiliated insurer. It equals 1 if the insurer is nonaffiliated and 0 if it is affiliated. Finally, the demutual_firm dummy equals 1 if the insurer is the demutualized insurer and 0 otherwise. On the other hand, the interaction terms of demutualized dummy variable and main firm-specific characteristics are also added into the regression model. They are labeled as demut dummy*(main firm-specific characteristics), respectively. The $R^{2}$, adjusted $R^{2}, F$ value, and samples used are also reported.

***significant at 1 percent, **significant at 5 percent, and *significant at 10 percent.

\section{Conclusions}

This study investigates whether converting property-liability insurers change their demand for reinsurance after conversion. Our regression results cannot reject the hypothesis that converting insurers reduce their demand for reinsurance after conversion. When we categorize the reinsurance purchase decision into two sources - from non-affiliated reinsurers and from affiliated reinsurers - we find that converting insurers decrease the demand for reinsurance from the non-affiliated reinsurers, but increase the demand for reinsurance from affiliated reinsurers after conversion. The result is robust when the sample consists of only non-M\&A insurers. A possible explanation is that converting insurers try to reduce total reinsurance costs through the purchase of reinsurance from affiliated reinsurers.

Consistent with the findings of Viswanathan and Cummins, ${ }^{53}$ we also find that converting insurers use more reinsurance from non-affiliated reinsurers than their

\footnotetext{
${ }^{53}$ Viswanathan and Cummins (2003).
} 
mutual counterparts before their conversion. This result is in contrast to the result of the demand for reinsurance after conversion. Our conjecture is that converting insurers use more reinsurance from non-affiliated reinsurers to improve their financial statements such that the conversion can be approved by policyholders and regulators before their conversion.

Other major findings are summarized below. First, the evidence implies that converting insurers with higher profits decrease overall reinsurance after conversions. Second, we find that converting insurers with higher leverage would increase demand for reinsurance from non-affiliated reinsurers but decrease demand from affiliated reinsurers after conversions. One possible explanation is that converting insurers try to protect themselves from bankruptcy. Finally, the evidence shows that firm size is negatively related to the demand for reinsurance.

\section{References}

Barber, B.M. and Lyon, J.D. (1996) 'Detecting abnormal operating performance: The empirical power and specification of test statistics', Journal of Financial Economics 41: 359-399.

Cole, C.R. and McCullough, K.A. (2006) 'A reexamination of the corporate demand for reinsurance', Journal of Risk and Insurance 73: 169-192.

Christensen, T.E., Hoyt, R.E. and Paterson, J.S. (1999) 'Ex ante incentive or earnings management and the informativeness of earning', Journal of Business Finance and Accounting 26: 807-832.

D’Arcy, S.P. and Garven, J.R. (1990) 'Property-liability insurance pricing models: An empirical evaluation', Journal of Risk and Insurance 57: 391-430.

Das, M., Newey, W.K. and Vella, F. (2003) 'Nonparametric estimation of sample selection models', The Review of Economic Studies 70: 33-58.

Esho, N., Kirievsky, A., Ward, D. and Zurbruegg, R. (2004) 'Law and the determinants of property-casualty insurance', Journal of risk and Insurance 71: 265-283.

Fitzgerald, J.F. (1973) 'Demutualization of mutual property and liability insurers', Journal of Risk and Insurance 40: 575-584.

Garven, J.R. and Lamm-Tennant, J. (2003) 'The demand for reinsurance: Theory and empirical tests', Assurances 71: 217-238.

Gaver, J.J. and Paterson, J.S. (1999) 'Managing insurance company financial statements to meet regulatory and tax reporting goals', Contemporary Accounting Research 16: 207-241.

Grace, E.V. (1990) 'Property-liability insurer reserve errors: A theoretical and empirical analysis', Journal of Risk and Insurance 57: 28-46.

Hoyt, R.E. and Khang, H. (2000) 'On the demand for corporate property insurance', Journal of Risk and Insurance 67: 91-107.

Jeng, V., Lai, G.C. and McNamara, M.J. (2007) 'Efficiency and demutualization: Evidence from the U.S. life insurance industry in the 1980s and 1990s', Journal of Risk and Insurance 74: 683-711.

Klaauw, B.V. and Koning, R.H. (2003) 'Testing the normality assumption in the sample selection model with an application to travel demand', Journal of Business and Economic Statistics 21: 31-42.

Kim, W.J., Mayers, D. and Smith, C.W. (1996) 'On the choice of insurance distribution systems', Journal of Risk and Insurance 63: 207-227.

Mayers, D. and Smith, C.W. (1990) 'On the corporate demand for insurance: Evidence from the reinsurance market', Journal of Business 63: 19-40.

Mayers, D. and Smith, C.W. (2004) 'Incentive for managing accounting information: Property-liability insurer stock-charter conversions', Journal of Risk and Insurance 71: 213-251.

McNamara, M.J. and Rhee, S.G. (1992) 'Ownership structure and performance: The demutualization of life insurers', Journal of Risk and Insurance 59: 221-238.

Nohel, T. and Tarhan, V. (1998) 'Share repurchases and firm performance: New evidence on the agency costs of free cash flow', Journal of Financial Economics 49: 187-222. 
Petroni, K.R. (1992) 'Optimistic reporting in the property-casualty insurance industry', Journal of Accounting and Economics 15: 485-508.

Powell, L.S. and Sommer, D.W. (2007) 'Internal versus external capital markets in the insurance industry: The role of reinsurance', Journal of Financial Services Research 31: 173-188.

Smith, C.W. and Stulz, R. (1985) 'The determinates of firms' hedging policies', Journal of Financial Economics 32: 263-292.

Studenmund, A.H. (1997) Using Econometrics: A Practical Guide, 3rd edn., New York: Addison-Wesley.

Viswanathan, K.S. (2006) 'The pricing of insurer demutualization initial public offerings', Journal of Risk and Insurance 73: 439-468.

Viswanathan, K.S. and Cummins, J.D. (2003) 'Ownership structure changes in the insurance industry: An analysis of demutualization', Journal of Risk and Insurance 70: 401-437.

Weiss, M. (1985) ‘A multivariate analysis of loss reserving estimates in property-liability insurers', Journal of Risk and Insurance 52: 199-221.

Weiss, M.A. and Chung, J. (2004) 'U.S. reinsurance price, financial quality, and global capacity', Journal of Risk and Insurance 71: 437-467.

\section{Appendix}

See Table A1

Table A1 List of demutualization insurers

\begin{tabular}{|c|c|c|}
\hline No. & Property-liability mutual insurers & Conversion year \\
\hline 1 & American Mutual Fire Insurance Co. & 1991 \\
\hline 2 & Health Care Insurance Exchange & 1991 \\
\hline 3 & Mutual Assurance & 1991 \\
\hline 4 & Progressive Mutual Insurance Co. & 1991 \\
\hline 5 & Safety Mutual Casualty Co. & 1991 \\
\hline 6 & AAOMS Mutual Insurance Co, RRG & 1992 \\
\hline 7 & Minnesota Mutual Fire \&Casualty Co. & 1993 \\
\hline 8 & Pioneer Mutual Insurance Co. & 1993 \\
\hline 9 & Prairie State Farmers Insurance Association & 1993 \\
\hline 10 & Union Automobile Indenmenity Association & 1993 \\
\hline 11 & Delaware Mutual Insurance Co. & 1994 \\
\hline 12 & Georgia Mutual Insurance Co. & 1994 \\
\hline 13 & Union Mutual Insurance Co. of Providence & 1994 \\
\hline 14 & Interstate Bankers Mutual Casualty Co. & 1995 \\
\hline 15 & Mutual Fire Insurance Co. of Saco, Me & 1995 \\
\hline 16 & Farm Family Mutual Insurance Co. & 1996 \\
\hline 17 & Preferred Physicians Mutual RRG & 1996 \\
\hline 18 & Goschenhoppen-Home Mutual Insurance Co. & 1997 \\
\hline 19 & National Chiropractic Mutual Insurance Co. & 1997 \\
\hline 20 & Old Guard Mutual Fire Insurance Co. & 1997 \\
\hline 21 & Old Guard Mutual Insurance Co. & 1997 \\
\hline 22 & Patrons Oxford Mutual Insurance Co. & 1997 \\
\hline 23 & Allegheny Mutual Casualty Co. & 1998 \\
\hline 24 & Southern Michigan Mutual Insurance Co. & 1998 \\
\hline 25 & FCCI Mutual Insurance Co. & 1998 \\
\hline 26 & Pioneer Mutual Insurance Co. & 1998 \\
\hline 27 & MI Educational Employees Mutual Insurance Co. & 1999 \\
\hline
\end{tabular}


Table A1 (continued)

\begin{tabular}{llc}
\hline No. & Property-liability mutual insurers & Conversion year \\
\hline 28 & Penn Millers Mutual Insurance Co. & 1999 \\
29 & Farmers Casualty Company Mutual & 1999 \\
30 & Medical Inter-insurance Exchange & 1999 \\
31 & Attorneys Liability Protection Society Inc., A Mutual Risk Retention Group & 2000 \\
32 & Millers Mutual Insurance Company & 2000 \\
33 & Florida Family Mutual Insurance Company & 2001 \\
34 & First Commercial Mutual Company & 2002 \\
35 & First Nonprofit Mutual Insurance Company & 2002 \\
36 & Millers Mutual Insurance Association & 2003 \\
\hline
\end{tabular}

\section{About the Authors}

Jennifer Wang is Associate Professor in the Department of Risk Management and Insurance at National Cheng-Chi University in Taiwan. She is Associate Editor of the Journal of Insurance Issue. Professor Wang also serves as a board member of the AsiaPacific Risk and Insurance Association (APRIA) and on the Board of Governors for the Pension Funds Association in Taiwan. She is also a research fellow of the China Center for Insurance and Social Security Research in Peking University in China.

Vincent Y. Chang is a PhD student in the Finance Department at National Taiwan University in Taiwan.

Gene C. Lai is Department Chair and Safeco Distinguished Professor of Insurance in the Department of Finance, Insurance, and Real Estate at Washington State University in the United States. He is Co-editor of the Journal of Insurance Issue and the associate editor of the Journal of Risk and Insurance. Professor Lai also serves as a board member of the American Risk and Insurance Association (ARIA) and of the Asia-Pacific Risk and Insurance Association (APRIA).

Larry Y. Tzeng is Professor in the Finance Department at National Taiwan University in Taiwan. He is the associate editor of the Journal of Risk and Insurance. Professor Tzeng also serves as a research fellow of the China Center for Insurance and Social Security Research in Peking University in China. 